\title{
Light Enhancement of the Second Positive Phototropic Curvature in Dark-grown Radish Seedlings
}

\author{
Hisashi Kato-NogUCHI \\ Department of Bioresource Science, Faculty of Agriculture, Kagawa University, \\ Miki-cho, Kagawa 761-07, Japan
}

(Received February 13, 1997)

\begin{abstract}
Phototropic sensitivity in hypocotyls of dark-grown, 4-d-old radish seedlings ( $R a$ phanus sativus L. cv. Miyashige) was investigated with reference to the influence of pre-exposure treatment. The magnitude of the second positive phototropic curvature in response to continuous unilateral irradiation was increased when the seedlings were pre-exposed with white light from above. This effect of the pre-exposure on the phototropic sensitivity increased with duration of the treatment and reached a plateau $3 \mathrm{~h}$ after the onset of the treatment. The pre-exposure treatment on the hypocotyls was only efficient to enhance the phototropic sensitivity, but the treatments on the apex and cotyledons have no effect. These results suggest that the site of perception of the pre-exposure light to enhance the phototropic sensitivity could be located within the phototropically responding organ, hypocotyl itself.
\end{abstract}

\section{INTRODUCTION}

Since the observation of phototropism by Darwin (1897) that seedlings of plants bend towards the light source when they are exposed to a lateral light, a great deal of research has been made to elucidate the mechanism of this phototropic curvature (Dennison, 1979 ; Pickard, 1985). Action-spectrum studies showed that the most effective light for the response is blue region (Curry, 1969; Dennison, 1979). Dose-response studies showed that the response exhibits energy dependency ; many dark-grown seedlings show first positive, then indifferent, and then second positive curvature as the energy in the light stimulus is increased (Zimmerman and Briggs, 1963 ; Briggs, 1964 ; Iino et al., 1984).

In the hypocotyls curvature of several dicotyledonous plant species, it has been reported that light-grown seedlings respond to a much larger extent to lateral light irradiation than dark-grown ones (Franssen and Bruinsma, 1981; Hart and MacDonald, 1981). Also phototropic sensitivity of dark-grown seedlings was increased by pre-exposure treatments with red light (Kang and Burg, 1974) or blue light (Franssen and Bruinsma, 1981), and with white light (Hart and MacDonald, 1981). However, the action-spectrum and perception site of pre-exposure light to enhance the phototropic sensitivity as well as this enhancement mechanism is not fully understood.

The purpose of this research was to investigate the perception site of the pre-exposure light to enhance phototropic sensitivity in dark-grown radish seedlings and to determine the light requirement of the seedlings for the development of sensitivity. 


\section{MATERIALS AND METHODS}

Plant material: Seeds of radish (Raphanus sativus L. cv. Miyashige) were germinated in moist vermiculite in the dark at $25^{\circ} \mathrm{C}$ for $3 \mathrm{~d}$. Seedling having hypocotyls of $10-15 \mathrm{~mm}$ in length were selected and transferred to plastic containers $(12 \times 25 \times 10$ (height) $\mathrm{cm})$ filled with fresh vermiculite. After being kept in the dark at $25^{\circ} \mathrm{C}$ for $1 \mathrm{~d}$, the 4-d-old dark-grown seedlings (hypocotyl length about $40 \mathrm{~mm}$ ) were used for phototropic experiments. All handling after sowing was performed under dim green safe-light $\left(0.003 \mathrm{~W} \mathrm{~m}^{-2}\right)$.

Phototropic experiments : Phototropic experiments were carried out in a non-reflecting black box (Fig. 1). Seedlings were placed at $35 \mathrm{~cm}$ distance from a white fluorescent lamp (Fl-20S-PG, National, Tokyo) in a small black box with a 3-cm wide, horizontal slit. The unilateral irradiation was given over the whole of the seedlings continuously at an intensity of $0.1 \mathrm{~W} \mathrm{~m}^{-2}$. The phototropic curvature was determined every $20 \mathrm{~min}$, by measuring the angle between the hypocotyl base and the tangent to the apex of the seedlings with a protractor (Fig. 2).

Pre-exposure treatments were carried out in the following way. The 4-d-old dark-grown seedlings were exposed continuously from above with a white fluorescent lamp $\left(0.1 \mathrm{~W} \mathrm{~m}^{-2}\right.$ at plant level) for 0.5 to $4.5 \mathrm{~h}$ at $25^{\circ} \mathrm{C}$ just before the phototropic experiments.

To investigate the perception site of the pre-exposure light, the hypocotyls or the apex and cotyledons of the seedlings were covered with aluminum foil or transparent plastic film during the pre-exposure treatments. The actions, both covering and removal, were performed carefully to avoid stress to the seedlings.



Fig. 1 A cross-section of the non-reflecting black box.

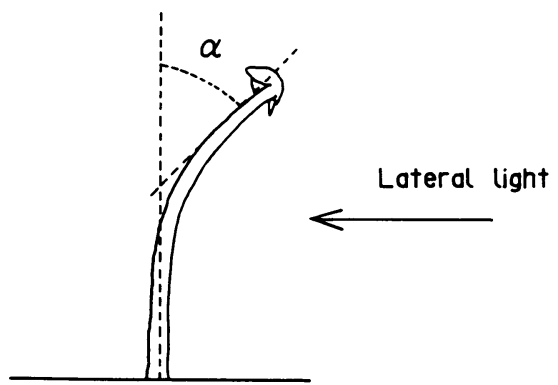

Fig. 2 The angle of curvature measured in hypocotyls of the radish seedlings. 


\section{RESULTS AND DISCUSSION}

Figure 3 shows the time course of the change in phototropic curvature of the 4-d-old dark-grown radish seedlings after the onset of continuous unilateral irradiation. The phototropic curvature started after a 20 min lag-time and increased until $100 \mathrm{~min}$. After this time the seedlings started to curve back, which may result from interference in the phototropic curvature by gravitropic and autotropic straightening (Shen-Miller and Gordon, 1967; Orbovic and Poff, 1991). The continuous unilateral irradiation at $0.1 \mathrm{~W} \mathrm{~m}^{-2}$ could induce the second positive phototropic curvature according to the phototropic dose-response relations for radish seedlings (Steyer, 1967 ; Everett, 1974).

Pre-exposure treatment increased the phototropic sensitivity in the dark-grown seedlings (Fig. 4). By $100 \mathrm{~min}$, the phototropic curvature of the pre-exposed seedlings increased about 1.5-fold compared with that of the dark-grown seedlings (Figs. 3 and 4). However, the shapes of their time courses as well as the lag-times were similar.

To investigate the light requirement of the dark-grown seedlings for the development of the phototropic sensitivity, the dark-grown seedlings were pre-exposed with white light from



Fig. 3 Changes in phototropic curvature of dark-grown radish seedlings. Dark-grown, 4-d-old seedlings were irradiated with a unilateral light at $0.1 \mathrm{~W} \mathrm{~m}^{-2}$, and the curvature of the hypocotyls was measured (O). Control plants remained in total darkness $(\bigcirc)$. Means \pm SE from 3 replicate experiments with 20 plants each are shown.

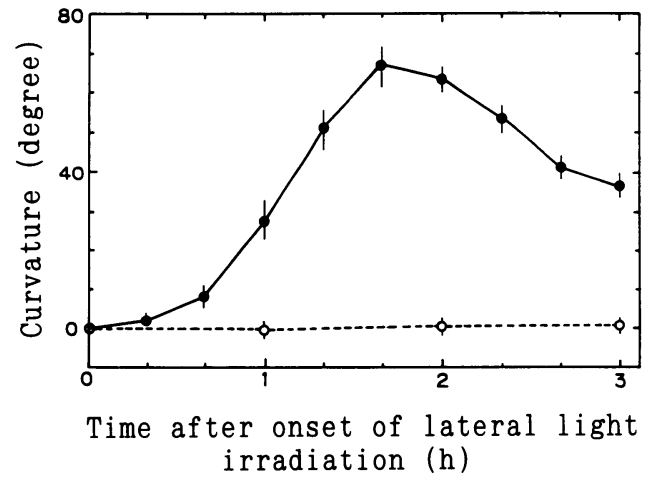

Fig. 4 Changes in phototropic curvature of pre-exposed dark-grown radish seedlings. Dark-grown, 4-d-old seedlings were pre-exposed with light from above for $3 \mathrm{~h}$ at $0.1 \mathrm{~W} \mathrm{~m}^{-2}$, and they were unilaterally irradiated and their curvatures were measured (O). Control plants remained in total darkness $(\bigcirc)$. Means \pm SE from 3 replicate experiments with 20 plants each are shown. 


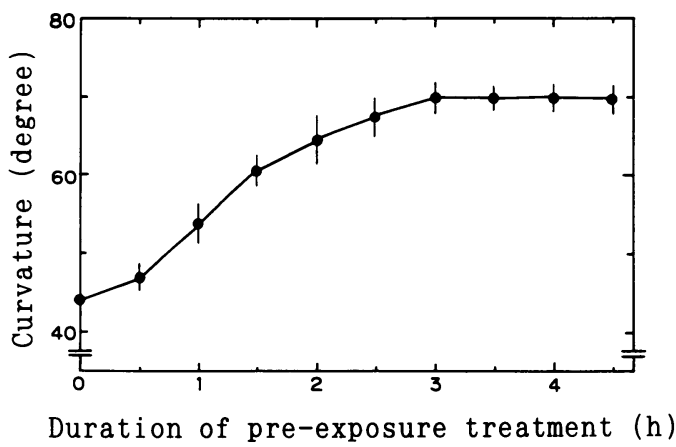

Fig. 5 Effects of various duration of pre-exposure treatments on the phototropic curvature. Dark-grown, 4-d-old seedlings were pre-exposed from above for different periods of time just before unilateral irradiation. The curvature was measured after $100 \mathrm{~min}$ unilateral irradiation. Means $\pm \mathrm{SE}$ from 3 replicate experiments with 20 plants each are shown.

Table 1 The influences of covering with opaque film on the phototropic curvature during pre-exposure treatment.

\begin{tabular}{lcc}
\hline \multirow{2}{*}{ Treatments } & \multicolumn{2}{c}{ Curvature (degree) } \\
\cline { 2 - 3 } & $\begin{array}{c}\text { Dark-grown } \\
\text { seedlings }\end{array}$ & $\begin{array}{c}\text { Pre-exposed } \\
\text { seedlings }\end{array}$ \\
\hline Intact & $45 \pm 7$ & $68 \pm 5$ \\
Apex and cotyledons covered & $43 \pm 5$ & $65 \pm 6$ \\
Hypocotyl covered & $42 \pm 6$ & $43 \pm 7$ \\
\hline
\end{tabular}

The hypocotyls or the apex and cotyledons of the 4-d-old dark-grown seedlings were covered with aluminum foil during 3-h pre-exposure treatment, and then, the foil was removed and the seedlings were unilaterally irradiated. The phototropic curvature was measured after $100 \mathrm{~min}$ unilateral irradiation. Intact seedlings were not covered during the pre-exposure treatment. Means \pm SE from 3 replicate experiments with 20 plants each are shown.

above for different periods of time. Subsequently they were unilaterally irradiated and their curvatures were measured after 100 min of unilateral irradiation, at which point of time most seedlings had reached their maximum curvature. The phototropic sensitivity started to develop rapidly and reached plateau value after $3 \mathrm{~h}$ (Fig. 5). This result indicates that 3-h pre-exposure with white light at $0.1 \mathrm{~W} \mathrm{~m}^{-2}$ is sufficient to enhance phototropic sensitivity of the dark-grown seedlings.

The site of perception of the light to enhance the phototropic sensitivity was also investigated. The hypocotyls or the apex and cotyledons of the dark-grown seedlings were covered with aluminum foil during 3-h pre-exposure treatment. After removing the foil, the seedlings were unilaterally irradiated and their curvatures were measured after $100 \mathrm{~min}$. The effect of the pre-exposure on the curvature disappeared by covering the hypocotyl, whereas covering the apex and cotyledons was ineffective in the development of the phototropic sensitivity (Table 1). These results indicate that the pre-exposure of the hypocotyls only induced the development of the phototropic sensitivity; the pre-exposure of the apex and cotyledons had no effect.

There is a possibility that the hypocotyls is so stressed by covering treatment that no induction of the development of the phototropic sensitivity could occur. To investigate the effect of this stress on the phototropic curvature, the seedlings were covered with transparent plastic film. Table 2 shows the covering treatments of the seedlings did not interfere with the phototropic curvature. As shown in Table 1, the hypocotyls of the seedlings seemed to have 
Table 2 The influences of covering with transparent film on the phototropic curvature during pre-exposure treatment.

\begin{tabular}{lcc}
\hline \multirow{2}{*}{ Treatments } & \multicolumn{2}{c}{ Curvature (degree) } \\
\cline { 2 - 3 } & $\begin{array}{c}\text { Dark-grown } \\
\text { seedlings }\end{array}$ & $\begin{array}{c}\text { Pre-exposed } \\
\text { seedlings }\end{array}$ \\
\hline Intact & $44 \pm 5$ & $62 \pm 6$ \\
Apex and cotyledons covered & $41 \pm 7$ & $64 \pm 4$ \\
Hypocotyl covered & $43 \pm 6$ & $63 \pm 7$ \\
\hline
\end{tabular}

The hypocotyls or the apex and cotyledons of the 4-d-old dark-grown seedlings were covered with transparent plastic film during the pre-exposure treatment. Other conditions were as described in the legend to Table 1.

influence on the development of the phototropic sensitivity.

In conclusion, the second positive phototropic curvature in the dark-grown radish seedlings was enhanced by the pre-exposure treatment with white light. The effect of the preexposure treatments on the phototropic sensitivity increased rapidly and leveled off $3 \mathrm{~h}$ after the onset of the treatments. The covering experiments indicate that the apex and cotyledons of the seedlings have no effect on the development of this phototropic sensitivity, and the pre-exposure of only the hypocotyls renders the seedlings more sensitive in phototropism. Thus, it is concluded that the site of perception of the light to enhance the phototropic sensitivity could be located within the phototropic responding organ, hypocotyl itself.

\section{REFERENCES}

Briggs, W. R. 1964. Phototropism in higher plants. In "Photophysiology" (ed. by Giese, A. C.), Academic Press, London, p 223-271.

Curry, G. M. 1969. Phototropism. In "The Physiology of Plant Growth and Development" (ed. by Wilkins, M. B.), McGraw-Hill, New York, p 241-273.

Darwin, C. 1897. The Power of Movement in Plants. D. Appleton, New York, pp 592.

Dennison, D. S. 1979. Phototropism. In "Physiology of Movements" (ed. by Haupt, W., Feinleib, M. E.), Encyclopedia of Plant Physiology Vol. 7. Springer-Verlag, Berlin, p 506-566.

Everett, M. 1974. Dose-response curves for radish seedling phototropism. Plant Physiol. 54 : 222-225.

Franssen, J. M., Bruinsma, J. 1981. Effects of different wavelengths on phototropic sensitivity of sunflower Helianthus annuus seedlings. Phytomorphology 30 : 344-358.

Hart, J. W., MacDonald, I. R. 1981. Phototropic responses of hypocotyls of etiolated and green seedlings. Plant Sci. Lett. 21 : 151-158.

Iino, M., Briggs, W. R., Schäfer, E. 1984. Phytochrome-mediated phototropism in maize seedling shoots. Planta 160 : 41-51.

Kang, B. G., Burg, S. P. 1974. Red light enhancement of the phototropic response of etiolated pea stems. Plant Physiol. 53 : 445-448.

Orbović, V., Poff, K. L. 1991. Kinetics for phototropic curvature by etiolated seedlings of Arabidopsis thaliana. Plant Physiol. 97 : 1470-1475.

Pickard, B. G. 1985. Roles of hormones in phototropism. In "Hormonal Regulation of Development III" (ed. by Pharis, R. P., Reid, D. M.), Encyclopedia of Plant Physiology Vol. 11. Springer-Verlag, Berlin, p 365-417.

Shen-Miller, J., Gordon, S. A. 1967. Gravitational compensation and the phototropic response of oat coleoptiles. Plant Physiol. 42 : 352-360.

Steyer, B. 1967. The dose response relations in geotropic and phototropic stimulation : comparison of mono- with dicotyledonous plants. Planta $77: 277-286$. 
Zimmerman, B. K., Briggs, W. R. 1963. Phototropic dosage-response curves for oat coleoptiles. Plant Physiol. 38 : 248-253.

\title{
〈和文抄録〉
}

\section{暗所で育てたダイコン芽生えに於ける光による光屈性 二次正屈曲反応の促進}

\author{
加藤 尚
}

香川大学農学部

暗所で育てた 4 日齢のダイコン (品種 宮重) 芽生えに於いて, 芽生えの下胚軸の光屈性反応を 増加させる前照射処理の影響について調べた. 芽生えの上方からの白色光照射による前処理は, そ の後の横方向からの白色光に対する光屈性二次正屈曲反応を増加させた。この前処理の光屈性反 応に対する効果は, 前処理の時間とともに増加し 3 時間で飽和した。この前処理は, 芽生えの下胚 軸に行ったときだけ光屈性反応を促進させ, 芽生えの先端部や子葉に行っても効果は無かった。以 上の結果は, 光屈性反応を増加させるこの前処理の光は, 光屈性の反応器官である下肧軸自体で感 受される事を示唆している。 